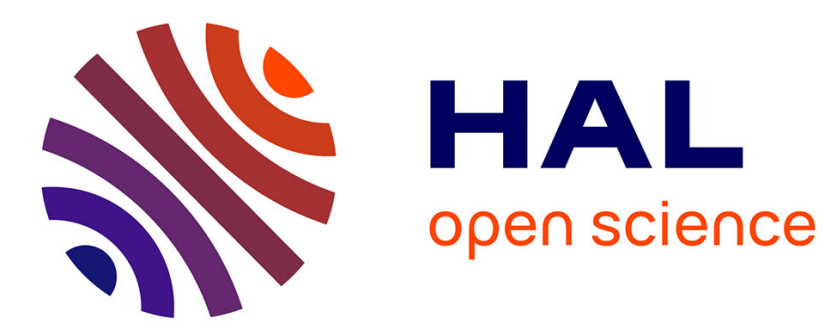

\title{
Changes in structure and fertilizing ability of marine and preshwater fish spermatozoa diluted in media of various salinities
}

Roland Billard

\section{- To cite this version:}

Roland Billard. Changes in structure and fertilizing ability of marine and preshwater fish spermatozoa diluted in media of various salinities. Aquaculture, 1978, 14 (3), pp.187-198. 10.1016/00448486(78)90094-7 . hal-01600749

\section{HAL Id: hal-01600749 \\ https://hal.science/hal-01600749}

Submitted on 2 Jun 2020

HAL is a multi-disciplinary open access archive for the deposit and dissemination of scientific research documents, whether they are published or not. The documents may come from teaching and research institutions in France or abroad, or from public or private research centers.
L'archive ouverte pluridisciplinaire HAL, est destinée au dépôt et à la diffusion de documents scientifiques de niveau recherche, publiés ou non, émanant des établissements d'enseignement et de recherche français ou étrangers, des laboratoires publics ou privés.

\section{다(1)(2)}

Distributed under a Creative Commons Attribution - ShareAlikel 4.0 International 


\title{
CHANGES IN STRUCTURE AND FERTILIZING ABILITY OF MARINE AND FRESHWATER FISH SPERMATOZOA DILUTED IN MEDIA OF VARIOUS SALINITIES
}

\author{
R. BILLARD
}

Laboratoire de Physiologie des Poissons, Institut National de la Recherche Agronomique, 78350 Jouy en Josas (France)

(Received 23 March 1978; revised 14 April 1978)

\begin{abstract}
Billard, R., 1978. Changes in structure and fertilizing ability of marine and freshwater fish spermatozoa diluted in media of various salinities. Aquaculture, 14: 187-188.

The spermatozoa of various marine teleosts (sea bass, Dicentrarchus labrax; sea bream, Sparus auratus) or fresh water teleosts (trout, Salmo gairdneri', pike, Esox lucius; guppy, Poecilia reticulata) were diluted in media of different salinities. Motility, morphological changes and fertilizing ability were the criteria used in judging the effects of such treatments. The medium best adapted to dilution of sea-fish sperm had a salinity of about $20 \%$. Sperm motility was increased and prolonged, and fertilization rate was significantly improved $(P<0.05)$ for the sea bass at a $1 / 1000$ dilution. For freshwater fish (trout and pike), an extender with about $7 \%$ salinity increased motility time and fertility ability $(P<0.01)$ as compared to freshwater. After dilution in fresh water the structure of trout spermatozoa was considerably altered (rupture of plasma membrane and mitochondrial swelling). When spermatozoa were diluted in the extender, there were no significant structural changes in trout, but alteration occurred in the mid-piece of the guppy spermatozoon. It is concluded that fresh water or sea water are not the best media for the practice of artificial insemination in freshwater or marine fish. Investigations should be carried out to define the best extender for use in techniques of artificial insemination in fish produced in aquaculture.
\end{abstract}

\section{RÉSUME}

Billard, R., 1978. Modification de la structure et du pouvoir fécondant des spermatozoides des poissons marins et d'eau douce dilués dans des milieux de différentes salinités. Aquaculture, 14: 187-198 (en anglais).

Les spermatozoīdes de divers poissons téléostéens appartenant à des espèces marines: Bar (Dicentrarchus labrax), Daurade (Sparus auratus); ou d'eau douce: Truite (Salmo gairdneri), Brochet (Esox lucius) ou Guppy (Poecilia reticulata) ont été dilués dans des milieux de différentes salinités. Les effets des traitements ont été appréciés par la motilité examinée sous microscope, les modifications morphologiques et le pouvoir fécondant. Le milieu le plus adapté à la dilution du sperme de poisson marin a une salinité d'environ $20 \%$. La motilité du sperme est augmentée et prolongée et le pourcentage de fécondation est significativement amélioré $(P<0,05)$ pour le Bar à la dilution de 1/1000. Pour les poissons 
d'eau douce (Truite et Brochet) l'emploi d'un dilueur dont la salinité est d'environ $7 \%$ augmente la durée de motilité et le pouvoir fécondant $(P<0,01)$ par rapport à l'eau douce. Après dilution dans l'eau douce, la structure du spermatozoïde est profondément modifiée chez la Truite ( rupture de la membrane plasmique, gonflement des mitochondries). Lorsque les spermatozoïdes sont dilués dans le dilueur, il n'ya pas de modifications notables de structure chez la Truite, mais des remaniements sont observés au niveau de la pièce intermédiaire du spermatozoïde de Guppy.

Il apparaît que l'eau douce ou l'eau de mer ne constituent pas les milieux les plus favorables pour la pratique de l'insémination artificielle. Des recherches doivent être conduites pour définir le meilleur diluant qui sera mis en oeuvre dans les techniques d'insémination artificielle pour les espèces de poissons produites en aquiculture.

\section{INTRODUCTION}

Most fish reproduction occurs in an aqueous medium and the spermatozoa are exposed for some time to the exterior environment before penetration of the egg. There are few data on the behavior of spermatozoa (motility, morphological changes) undergoing osmotic shock, and they mostly concern salmonids (Geiger, 1955; Ginsburg, 1963; Billard and Breton, 1970). We studied the behavior of spermatozoa of some marine and freshwater fish in media of various salinities in order to establish a diluent for artificial insemination.

\section{MATERIAL AND METHODS}

The freshwater guppy (Poecilia reticulata), rainbow trout (Salmo gairdneri) and pike (Esox lucius) were studied in the Fish Physiology laboratory at Jouy en Josas. Work on the marine species sea bass (Dicentrarchus labrax) and sea bream (Sparus auratus) was carried out at Sète (Station de Biologie marine) and at Brest (Centre Océanologique de Bretagne). The sea bass, sea bream, trout and guppy were raised in the laboratory (Billard, 1966). The pike were captured in a pond (Etang de Grandieu), transported to the laboratory before the reproduction period and kept in captivity in the dark in order to prevent fighting (Billard et al., 1976). Sperm was tested at the onset of sperm release. Sperm production in guppy being continuous, experiments were carried out at different times of the year.

Before sampling, animals were anesthetized in a solution of Quinaldine (sea bass and sea bream) or MS222 and Phenoxy-ethanol (Merck) (trout, pike and guppy). Sperm usually taken from 10 individuals was withdrawn from the genital papilla with a syringe after abdominal massage. The criteria used in studying the sperm were as follows.

\section{Motility and fertilizing ability}

Immediately after sampling, sperm were diluted 100-fold with distilled water or a NaCl-base physiological solution such as Ringer for guppy, or an extender 
buffered at $\mathrm{pH} 9$, previously described (Billard et al., 1974) for other fresh water species. Non-buffered diluted sea water was used for sperm of marine fish. Intensity of motility was estimated under a microscope $(X 100$, examination of five microscopic fields) using a scale of arbitrary units from 0 to 5 . Duration of motility was measured of the maintenance of the initial motility observed immediately after dilution of fresh sperm. Insemination and evaluation of fertilization percentage in trout have been described by Billard et al. (1974). Experiments were carried out at room temperature (rearing facilities): aboul $20^{\circ} \mathrm{C}$ for guppy, sea bass and sea brean, and $10^{\circ} \mathrm{C}$ for trout and pike (see Table I).

\section{Morphological changes}

The spermatozoa were fixed immediately after recovery or after having been in fresh water or physiological solutions. They were examined by electron microscopy after fixation using the following method; fixation in a glutaraldehyde solution $(0.05 \mathrm{M}$ phosphate buffer at $7.25 \mathrm{pH})$ for $30 \mathrm{~min}$ at $4^{\circ} \mathrm{C}$, then in a $2 \%$ osmic acid solution in the same buffer. After embedding in epon, the sections were stained with uranyl acetate $(5 \mathrm{~min})$ and lead citrate $(10 \mathrm{~min})$, covered with a carbon film and examined with a Siemens Elmiskop.

The morphological changes in trout spermatozoa after exposure to media of different salinities were also estimated by optical density changes, in the same conditions as used by Stoner and Sirak (1969) for mammalian mitochondria.

\section{Extender media used}

The composition of the fresh water was as follows: $\mathrm{pH} 6.6 ; 0.610^{-3} \mathrm{mho}$ conductivity; alkalinity $\left(\mathrm{HCO}_{3}\right): 170 \mathrm{mg} / 1 ; \mathrm{NO}_{3}: 23 \mathrm{mg} / 1 ; \mathrm{NO}_{2}: 0.08 \mathrm{mg} / 1$; $\mathrm{NH}_{4}: 0.5 \mathrm{mg} / \mathrm{l} ;$ orthophosphate $\left(\mathrm{PO}_{4}\right): 0.23 \mathrm{mg} / \mathrm{l} ; \mathrm{Ca}: 100 \mathrm{mg} / \mathrm{l} ; \mathrm{Mg}: 10 \mathrm{mg} / \mathrm{l}$; $\mathrm{Na}: 31 \mathrm{mg} / \mathrm{l} ; \mathrm{K}: 1.3 \mathrm{mg} / \mathrm{l}$.

The physiological solutions used were the insemination extender described in Billard (1977) for pike and trout, and the following medium (DCSB4) for sea bass and sea bream: $\mathrm{NaCl}: 19.5 \mathrm{~g} / \mathrm{l}$; glycine: $6.25 \mathrm{~g} / \mathrm{l} ; \mathrm{MgSO}_{4} 7 \mathrm{H}_{2} \mathrm{O}: 0.26 \mathrm{~g} / \mathrm{l}$; $\mathrm{CaCl}_{2} 2 \mathrm{H}_{2} \mathrm{O}: 0.25 \mathrm{~g} / \mathrm{l}$. Adjustment to $\mathrm{pH} 8.5$ was done with $0.02 \mathrm{M}$ Tris- $\mathrm{HCl}$. Diluted saltwater solutions $(1 / 1,1 / 1.5,1 / 2,1 / 3,1 / 5,1 / 10)$ were adjusted to pH 8.5 (0.02 M Tris-HCl buffer). Sperm were usually diluted 100 -fold $\left(10^{-2}\right)$.

\section{RESULTS}

Sperm motility time in different fish species

Non-diluted teleost spermatozoa were usually motionless. They became active after dilution in distilled water, fresh water or physiological solutions. Spermatozoa were only motile if salinity was lower than $15 \%$ for freshwater fish and higher than $10 \%$ for sea bream and sea bass. For the latter species, sperm dilution in saltwater solutions showed that optimal salinity is about $20 \%$ 
(Fig. 1). Guppy spermatozoa became motile spontaneously after dissociation of spermatozeugma (spermatozoon association). In this case, motility was evident for $48 \mathrm{~h}$ at $4^{\circ} \mathrm{C}$. After dilution in Ringer solution, motility time of guppy spermatozoa was much shorter and remained at its initial level for $1 \mathrm{~h}$ (Table I). Motility time for the other species was shorter; after dilution in fresh water the initial level of motility was retained for less than $1 \mathrm{~min}$ and stopped after $2 \mathrm{~min}$. In physiological solutions, initial motility was maintained for $5 \mathrm{~min}$, except in trout where it did not last more than $1 \mathrm{~min}$. Motility then decreased progressively for all species and stopped completeiy after 20-40 min.

The storage life of undiluted sperm, kept at $4^{\circ} \mathrm{C}$ after sampling is also shown in Table I. Intact sperm may remain motile for several days in guppy, sea bass and sea bream, but for only 24 and $12 \mathrm{~h}$ in the pike and trout, respectively. Adding an extender prolonged the survival (motility) of sperm when kept at temperatures slightly under $0^{\circ} \mathrm{C}: 6$ days for guppy and 11 days for trout.

Fertilization rate after insemination in natural medium (fresh water or salt water) and in extender

As can be seen from Table II the extender medium provided a more suitable

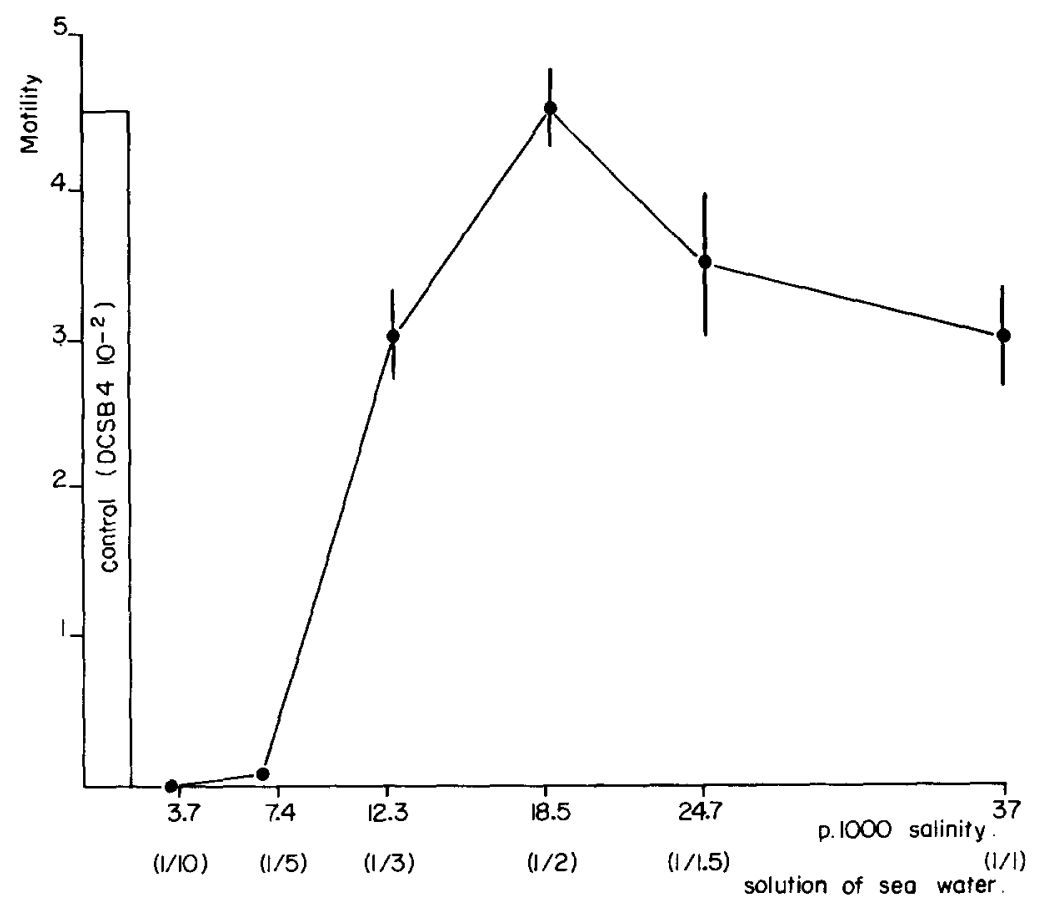

Fig. 1. Motility of sperm of Dicentrarchus labrax diluted with different concentrations of sea water. Motility in arbitrary units \pm SEM. 


\section{TABLE I}

Duration of motility following sperm dilution, and duration of fertilizing ability of nondiluted sperm of some species of teleosts. Values correspond to the duration of maintenance of the initial motility or fertilizing ability observed in freshly ejaculated semen

\begin{tabular}{|c|c|c|c|c|c|}
\hline \multirow[t]{3}{*}{ Species } & \multicolumn{3}{|c|}{ Duration of sperm motility after dilution } & \multirow{2}{*}{\multicolumn{2}{|c|}{$\begin{array}{l}\text { Duration of viability } \\
\text { of non-diluted sperm }\end{array}$}} \\
\hline & \multirow{2}{*}{$\begin{array}{l}\text { Temperature } \\
\left({ }^{\circ} \mathrm{C}\right)\end{array}$} & \multicolumn{2}{|l|}{ Diluent } & & \\
\hline & & $\begin{array}{l}\text { Fresh water } \\
\text { or sea water* } \\
(\min )\end{array}$ & $\begin{array}{l}\text { Physiological } \\
\text { medium } \\
\text { (diluant) } \\
\text { (min) }\end{array}$ & $\begin{array}{l}+4^{\circ} \mathrm{C} \\
\text { (intact } \\
\text { sperm) } \\
\text { (h) }\end{array}$ & $\begin{array}{l}\text { With } \\
\text { protector } \\
\text { (day) }\end{array}$ \\
\hline $\begin{array}{l}\text { Guppy } \\
\quad \text { Poecilia reticulata }\end{array}$ & 20 & 1 & 60 & 48 & $6(\text { yolk })^{1}$ \\
\hline $\begin{array}{l}\text { Sea bass } \\
\text { Dicentrarchus } \\
\text { labrax }\end{array}$ & 20 & $2 *$ & 6 & 70 & \\
\hline $\begin{array}{l}\text { Sea bream } \\
\quad \text { Sparus auralus }\end{array}$ & 20 & $2^{*}$ & 6 & 80 & \\
\hline $\begin{array}{l}\text { Pike } \\
\qquad \text { Esox cius }\end{array}$ & 10 & $0.5-1$ & $3-5$ & 24 & \\
\hline $\begin{array}{l}\text { Trout } \\
\quad \text { Salmo gairdneri }\end{array}$ & 10 & $0.25-0.5$ & $0.5-1$ & 12 & $11\left(\right.$ DMSO $^{2}$ \\
\hline
\end{tabular}

environment for fertilization than the usual medium. Fertilization rate dropped sharply when insemination was done in fresh water (pike and trout). The decrease was less sharp in salt water (sea bass) and percentages were significantly different only at the strongest dilution $\left(10^{-3}\right)$.

\section{Morphological changes in trout and guppy spermatozoa after dilution}

After immersion in fresh water and in saline solutions of increasing $\mathrm{NaCl}$ concentration, morphological changes occurred in fresh water and at a $\mathrm{NaCl}$ concentration of $30 \mathrm{~g} / \mathrm{l}$; these were expressed by progressive decrease in optical density (Fig. 2). A study in trout comparing the ultrastructure of freshly ejaculated, undiluted spermatozoa (Fig. 3.1) and those diluted in freshwater showed that morphological alterations occurred in the latter. After dilution in fresh water, structural changes could be identified after $30 \mathrm{~s}$. The plasma membrane around the sperm head became swollen (Fig. 3.2), and vesicles formed in the back part of the head at the insertion of the flagellum and in the midpiece. The latter, in ring form in the intact spermatozoon, was here thrown to one side. After $1 \mathrm{~min}$ in fresh water, further changes became evident. 
TABLE II

Percentage of fertilization (estimated from the percentage of embry onated eggs) following insemination of ova using a diluant: fresh water (trout, pike), or sea water (sea bass)

\begin{tabular}{|c|c|c|c|c|c|}
\hline \multirow[t]{2}{*}{ Species } & \multirow{2}{*}{$\begin{array}{l}\text { Concentration } \\
\text { of spermatozoa } \\
\times 10^{9}\end{array}$} & \multirow[t]{2}{*}{$\begin{array}{l}\text { Dilution } \\
\text { factor }\end{array}$} & \multicolumn{2}{|c|}{$\begin{array}{l}\text { Percentage of fertilization } \\
\text { after fertilization in: }\end{array}$} & \multirow{2}{*}{$\begin{array}{l}\text { Statistical } \\
\text { comparison } \\
\text { of percen- } \\
\text { tage of } \\
\text { fertilization }\end{array}$} \\
\hline & & & $\begin{array}{l}\text { Fresh water** } \\
\text { or sea water* }\end{array}$ & Diluant & \\
\hline $\begin{array}{l}\text { Sea bass } \\
\text { Dicentrarchus } \\
\text { labrax }\end{array}$ & 3.5 & $\begin{array}{l}10^{-2} \\
10^{-3}\end{array}$ & $\begin{array}{l}78^{*} \\
62^{*}\end{array}$ & $\begin{array}{l}85 \\
72\end{array}$ & $\begin{array}{l}\text { NS } \\
P<0.05\end{array}$ \\
\hline $\begin{array}{l}\text { Trout } \\
\quad \text { Salmo gairdneri }\end{array}$ & 8.5 & $\begin{array}{l}10^{-2} \\
10^{-3}\end{array}$ & $\begin{array}{l}63^{* *} \\
56^{* *}\end{array}$ & $\begin{array}{l}85 \\
76\end{array}$ & $\begin{array}{l}P<0.01 \\
P<0.01\end{array}$ \\
\hline $\begin{array}{l}\text { Pike } \\
\quad \text { Esox lucius }\end{array}$ & 22.0 & $\begin{array}{l}10^{-2} \\
10^{-3} \\
10^{-4}\end{array}$ & $\begin{array}{l}63^{* *} \\
52^{* *} \\
10^{* *}\end{array}$ & $\begin{array}{l}78 \\
71 \\
29\end{array}$ & $\begin{array}{l}P<0.01 \\
P<0.01 \\
P<0.01\end{array}$ \\
\hline
\end{tabular}

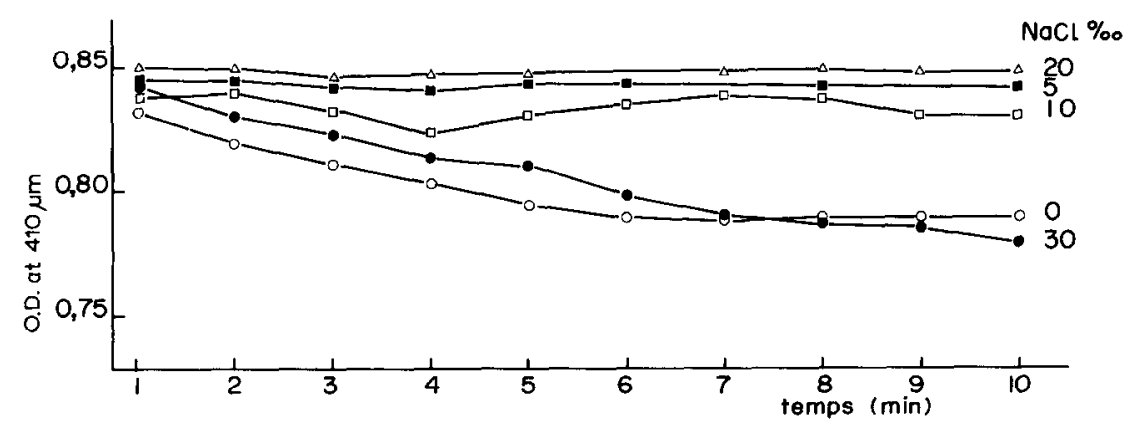

Fig. 2. Optical density of dilutions of trout spermatozoa at different salinities.

Firstly, the plasma membrane detached from the sperm head and flagellum, probably due to water penetration. The flagellum axis itself coiled up inside the plasma membrane (Fig. 4.1). In some cases, the mid-piece became disorganized and broke into small vesicles (Figs. 3.3 and 4.2). In others the midpiece seemed to condense into a single mitochondrion, remaining near the sperm head and pressed against the flagellum microtubules (Figs. 3.3 and 4.2): The two layers of the nuclear membrane separated and tended to detach from the sperm head (Fig. 3.2-3). There were less obvious changes after dilution in physiological solution; as compared to undiluted intact spermatozoa, a slight contraction of the mid-piece was observed $1 \mathrm{~min}$ after dilution (Fig. 4.3). This mid-piece was sometimes thrown to one side (Fig. 4.4).

Large structural alterations were also observed in the guppy. After dilution 

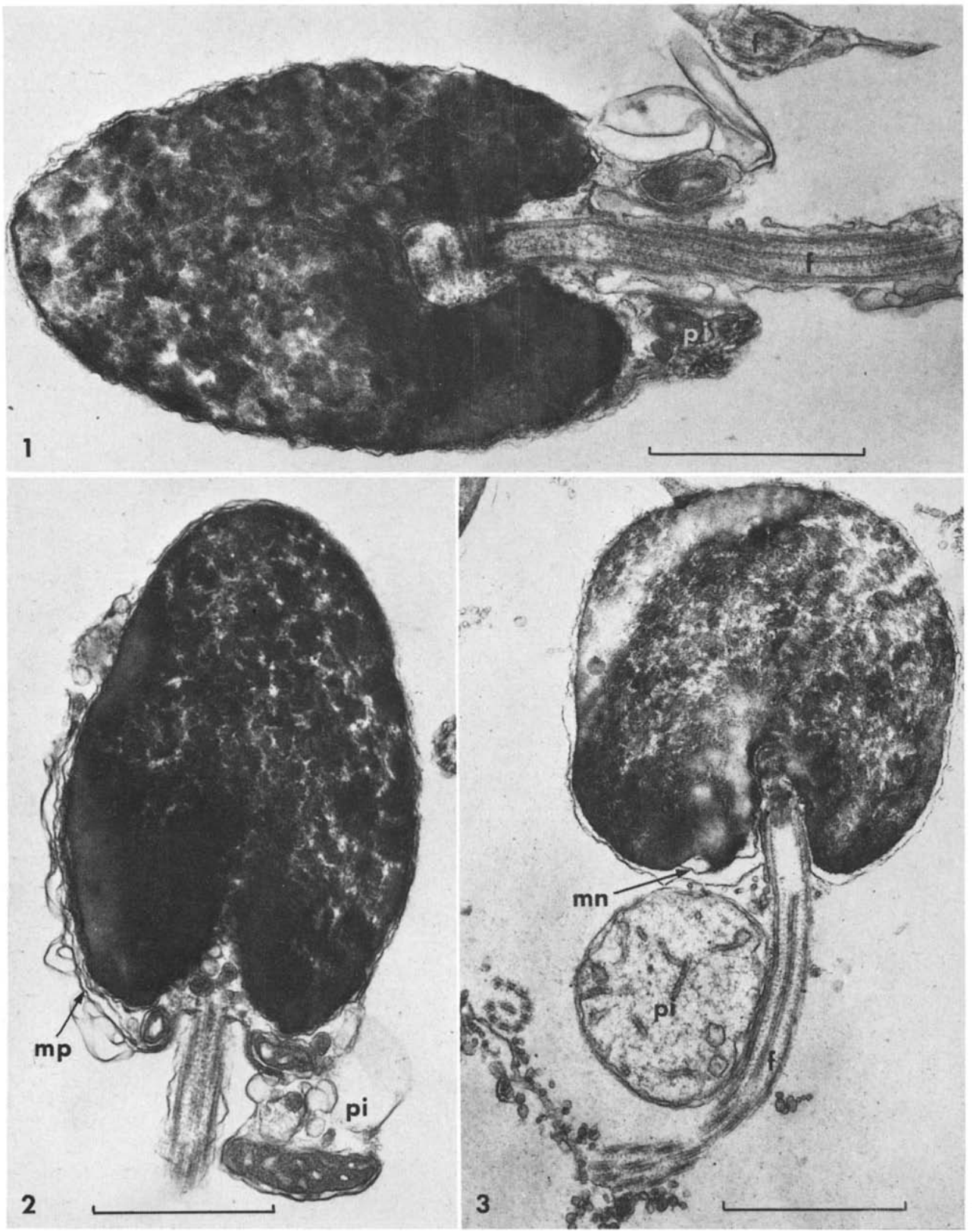

Fig. 3. Ultrastructure of trout (Salmo gairdneri) spermatozoa after dilution in fresh water. pi: mid-piece; $\mathrm{f}$ : flagellum; $\mathrm{mn}$ : nuclear membrane; $\mathrm{mp}$ : plasma membrane. Scale $1 \mu \mathrm{m}$.

(1) Freshly ejaculated and non-diluted spermatozoon.

(2) After dilution for $30 \mathrm{~s}$ in fresh water.

(3) After dilution for $5 \mathrm{~min}$ in fresh water. 


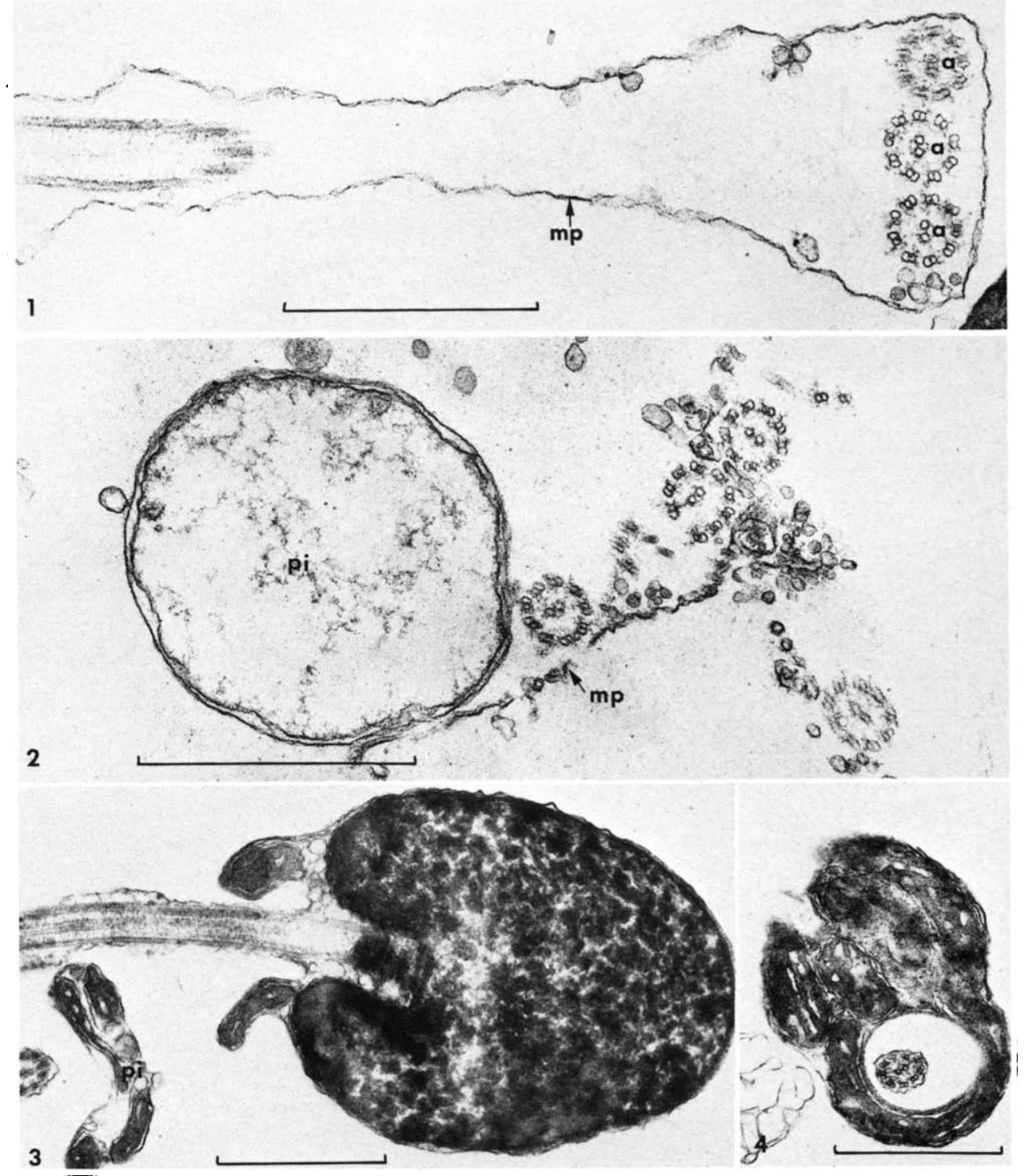

Fig. 4. Structural modifications of trout sperm after dilution. Scale $1 \mu \mathrm{m}$.

(1) Lifting of flagellum plasma membrane and twisting of the axoneme (a) inside the swollen plasma membrane after dilution for $5 \mathrm{~min}$ in fresh water.

(2) Swelling of the mid-piece and rupture of the plasma membrane.

(3) General morphology of a spermatozoon after $5 \mathrm{~min}$ exposure to the fertilization diluant.

(4) Cross section of the mid-piece of a spermatozoon after $30 \mathrm{~s}$ exposure to the fertilization diluant. 
in fresh water the same phenomenon of membrane swelling and rupture was seen as in trout. In Ringer saline however, changes occurred mostly in the mid-piece which is very developed in this species; the mitochondrial sheath may be $7 \mu \mathrm{m}$ long. In the intact freshly ejaculated spermatozoa, the mitochondria are very flat. After resting $20 \mathrm{~min}$ in Ringer they tended to swell and present membrane coils (Fig. 5.1-5). The fringe of cytoplasm next to the cytoplasmic canal increased in volume (Fig. 5.2) and the cytoplasm seemed to be incorporated at the center of the membrane coils (Fig. 5.3). After $30 \mathrm{~min}$, some of the midpieces observed were very reduced (Fig. 5.4) or dilated by mitochondrial swelling (Fig. 5.6).

\section{DISCUSSION}

Using motility time and fertilization rate as criteria, it may be concluded that the medium in which fertilization naturally occurs does not best enhance spermatozoon survival in any of the fishes studied. Huxley (1930) had already observed this in salmonids. It should also be noted that fertilization rate in fresh water tended to increase when sperm concentration was higher, and it is probable that in natural conditions, the number of spermatozoa per egg is higher than in the experiments of this report. It has also been shown in trout (Billard and Jalabert, 1974) and pike (De Montalembert and Billard, unpublished) that eggs did not retain their fertility after remaining more than 1 min in fresh water. The same results were found for eggs of sea bass, sea bream and turbot; the fertilizability of ovules, when put into salt water $(37 \%$ salinity) decreased after a few minutes (Billard, unpublished). Therefore, motility of spermatozoa, although short, is long enough for fertilization to occur provided that both spermatozoa and eggs are released simultaneously by the parents.

Motility time was longest in the guppy: several hours after spermatozeugma dissociation in seminal fluid and only one hour after dilution in Ringer. This medium was therefore not the best for sperm dilution in this species, whereas similar mineral solutions have proven very efficient as extenders in trout (Petit et al., 1973). The longer motility of guppy spermatozoa should be related to their structure and the reproductive biology of this species. Fertilization in this animal is internal; the spermatozoon, which does not appear to be put in contact with the exterior environment during mating, ascends to the ovary by the oviduct; there it can survive several months (Winge, 1937) in specialized storage structures (Jalabert and Billard, 1969). Moreover, the structure of this spermatozoon is one of the most complicated in teleost fish (Billard, 1970). The mid-piece is very developed and a large amount of glycogen is present (Billard and Jalabert, 1973). It is reduced to several mitochondria in other species studied where the amount of energy stores is more limited (Billard and Flechon, 1969). Therefore, the duration of motility of guppy spermatozoa, which is the longest among the species studied, may be related to the original structure of the spermatozoon.

it appears that fresh water or sea water are not the best media for the 

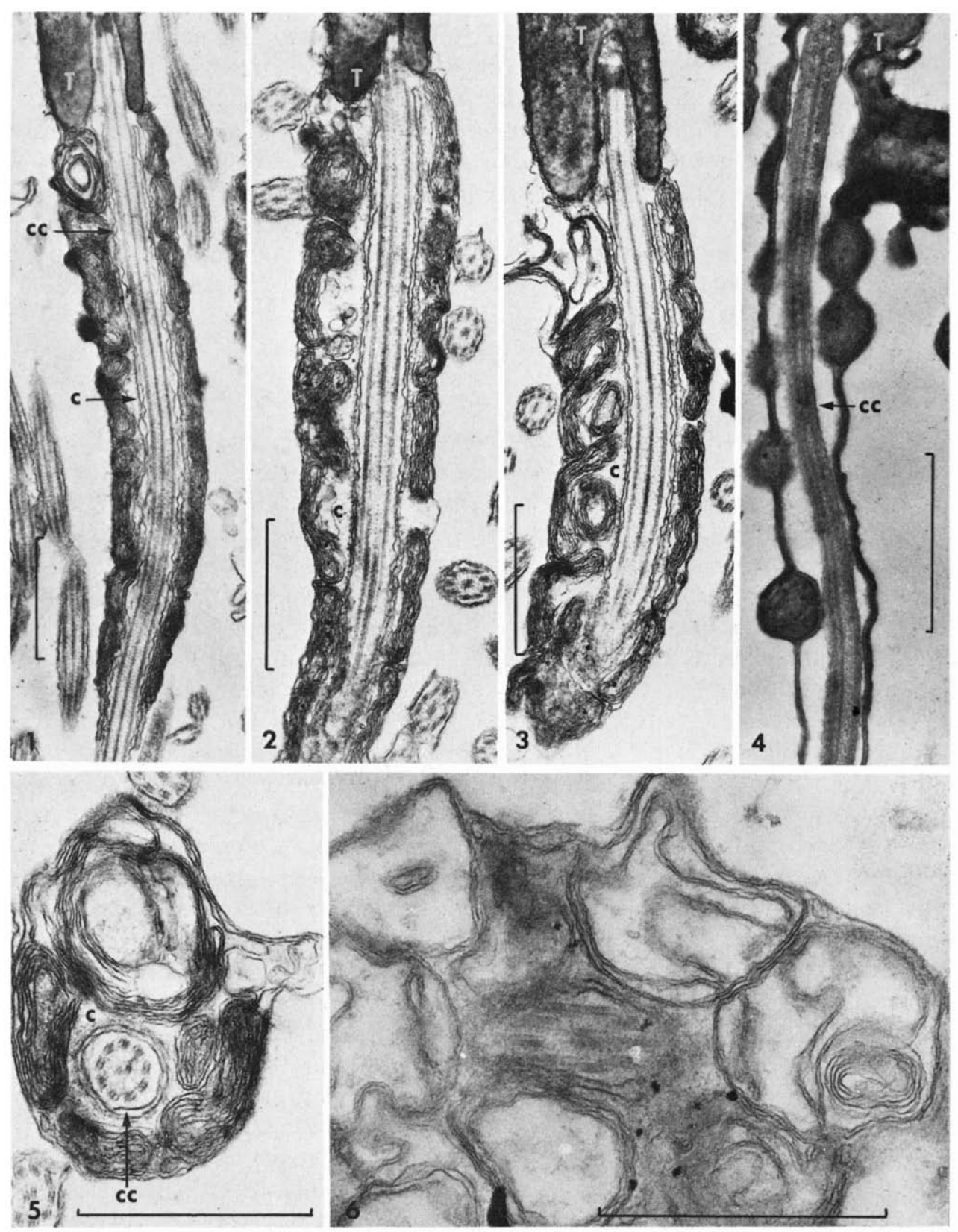

Fig. 5. Ultrastructural modifications of the mid piece of guppy spermatozoa after dilution, in a Ringer solution. Scale $1 \mu \mathrm{m}$. T: head of the spermatozoon; $c$ : cytoplasmic sheath; $c$ : cytoplasmic canal.

(1) After dilution for $5 \mathrm{~min}$.

(2) After dilution for $20 \mathrm{~min}$.

(3) After dilution for $20 \mathrm{~min}$.

(4) After dilution for $30 \mathrm{~min}$.

(5) Cross section of the mid-piece after dilution for $20 \mathrm{~min}$.

(6) Cross section of the mid-piece after dilution for $30 \mathrm{~min}$. 
survival of the spermatozoa of fresh water and marine fish. It is, therefore, necessary to use a specific extender in techniques of artificial insemination for the production of juveniles in hatcheries. Such an extender is now available for salmonids (Billard, 1977) and investigations are in progress to define the best media to be used in artificial insemination for marine fish which are candidates for mariculture.

\section{ACKNOWLEDGEMENTS}

This work was carried out in collaboration with the CNEXO and the CSP. We thank Mr Gilbert Barnabe and Michel Girin who gave us the breeding animals, as well as Miss Nisbet (CTGREF Paris) who did the water analysis.

We are also indebted to the Director of the Oceanographic Center of Brittany and of the Biological Station at Sète who let us use their laboratory facilities. We also wish to thank the Conseil Supérieur de la Pêche and its branch of Poitiers which gave us the pike used in these experiments. The paper was presented at the 2nd European Congress of the Ichthyologists.

We wish to thank Mrs Alice Daifuku for translating this text into English and $\mathrm{Mr}$ Gilles de Montalembert for help in pike sperm experiments.

\section{REFERENCES}

Billard, R, 1966. Influence de la température sur la durée et l'efficacité de la spermatogenèse de Guppy Poecilia reticulata. C.R. Acad. Sci., 266: 2287-2290.

Billard, R., 1970. La spermatogenèse de Poecilia reticulata. IV - La spermiogenèse. Etude ultrastructurale. Ann. Biol. Anim. Biochim. Biophys., 10: 493-510.

Billard, R., 1977. Utilisation d'un système tris-glycocolle pour tamponner le dilueur d'insémination pour truite. Bull. Fr. Piscic., 264: 102-112.

Billard, R. and Breton, B., 1970. Modifications ultrastructurales et cytochimiques des spermatozoīdes après dilution chez les poissons d'eau douce. Soc. Fr. Microsc. Electron., VIIème Congr. Intern. Microsc. Electron., Grenoble 1970, pp. 637-638.

Billard, R. and Flechon, J.E., 1969. Particularité de la pièce intermédiaire des spermatozoïdes de quelques poissons téléostéens. J. Microsc., 8: 36a.

Billard, R. and Jalabert, $F_{.,}, 1973$. Le glycogène au cours de la formation des spermatozoîdes et de leur transit dans le tractus génital femelle chez le Guppy (Poisson poecilidae). Ann. Biol. Anim. Biochim. Biophys., 13: 313-320.

Billard, R. and Jalabert, B., 1974. L'insémination artificielle de la truite (Salmo gairdneri Richardson). II - Comparison des effets de différents dilueurs sur la conservation de la fertilité des gamètes avant et après insémination. Ann. Biol. Anim. Biochim. Biophys., 14: $601-610$.

Billard, R., Petit, J., Jalabert, B. and Szollosi, D., 1974. Artificial insemination in trout using a sperm diluent. In: J.H.S. Blaxter (Editor), Symposium on the Early Life History of Fish. Oban, pp. 715-723.

Billard, R., Debruille, M., Gerard, J.P. and De Montalembert, G., 1976. L'insémination artificielle du Brochet. Bull. Fr. Piscic., 262: 30-35.

Geiger, N., 1955. Elektronenoptische Untersuchungen am Salmonidensperma. Rev. Suisse Zool., 62: 325-334. 
Ginsburg, A.S., 1963. Sperm-egg association and its relationship to the activation of the egg in salmonid fishes. J. Embryol. Exp. Morphol., 11:13-33.

Huxley, J.S., 1930. The maladaptation of trout spermatozoa to freshwater. Nature, 125: 494.

Jalabert, B. and Billard, R., 1969. Etude ultrastructurale du site de conservation des spermatozoïdes dans l'ovaire de Poecilia reticulata (Poisson téléostéen). Ann. Biol. Anim. Biochim. Biophys., 9: 283-280.

Petit, J., Jalabert, B., Chevassus, B. and Billard, R., 1973. L'insémination artificielle de la Truite. I - Effets du taux de dilution, du $\mathrm{pH}$ et de la pression osmotique du dilueur sur la fécondation. Ann. Hydrobiol., $4: 201-210$.

Sanchez-Rodriguez, M., 1975. Contribution à l'étude de l'Insémination artificielle de la Truite (Salmo gairdneri): les possibilités de la manipulation des gamètes et de la conservation du sperme. D.E.A. Université Paris VI, 21 pp.

Stoner, C.D. and Sirak, H.D., 1969. Osmotically induced alterations in volume and ultrastructure of mitochondria isolated from rat liver and bovine heart. J. Cell Biol., 43: $521-538$.

Winge, O., 1937. Succession of broods in Lebistes. Nature, 140: 467. 